The Mathematics of Various Entertaining Subjects

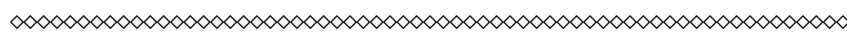





\title{
The Mathematics of Various Entertaining Subjects
}

\author{
RESEARCH IN RECREATIONAL MATH

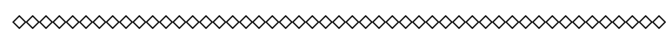 \\ EDITED BY \\ Jennifer Beineke \& Jason Rosenhouse
}

WITH A FOREWORD BY RAYMOND SMULLYAN 
Copyright (C) 2016 by Princeton University Press

Published by Princeton University Press, 41 William Street,

Princeton, New Jersey 08540

In the United Kingdom: Princeton University Press, 6 Oxford Street, Woodstock, Oxfordshire OX20 1TW

press.princeton.edu

In association with the National Museum of Mathematics,

11 East 26th Street, New York, New York 10010

\section{TWO SIGMA}

Jacket art: Clockwise: Row 1, Fig. 1: Courtesy of Anany Levitin;

Fig. 2: Cards and game, c. 1988, 1991. Cannei, LLC.

All rights reserved. SET ${ }^{\circledR}$ and all associated logos and tag lines are registered trademarks of Cannei, LLC. Used with permission from

SET Enterprises, Inc.; Fig. 3: Courtesy of John K. McSweeney.

Row 2, Fig. 4: Courtesy of Robert Bosch; Fig. 5: Courtesy of Burr Tools/

Andreas Röver; Fig. 6: Courtesy of Anany Levitin.

Row 3, Fig. 7: Courtesy of O. Encke, www.encke.net; Fig. 8: Courtesy of Anany Levitin; Fig. 9: Courtesy of Jennifer Beineke and Lowell Beineke.

All Rights Reserved

ISBN 978-0-691-16403-8

Library of Congress Control Number: 2015945218

British Library Cataloging-in-Publication Data is available

This book has been composed in Minion Pro

Printed on acid-free paper. $\infty$

Typeset by S R Nova Pvt Ltd, Bangalore, India

Printed in the United States of America

13579108642 